Democracy and War 



\title{
Democracy and War
}

\author{
Institutions, Norms, and the \\ Evolution of International Conflict
}

DAVID L. ROUSSEAU

Stanford University Press

Stanford, California

2005 
Stanford University Press

Stanford, California

(C) 2005 by the Board of Trustees of the Leland Stanford Junior University.

All rights reserved.

No part of this book may be reproduced or transmitted in any form or by any means, electronic or mechanical, including photocopying and recording, or in any information storage or retrieval system without the prior written permission of Stanford University Press.

Library of Congress Cataloging-in-Publication Data

Rousseau, David L.

Democracy and war : institutions, norms, and the evolution of international conflict / David L. Rousseau.

p. $\mathrm{cm}$.

Includes bibliographical references and index.

ISBN 0-8047-508 I-5 (cloth : alk. paper)

I. War-Political aspects-Case studies. 2. Democracy. I. Title.

JZ6385.R68 2005

327.I'17-dc22

2004018552

Original Printing 2005

Last figure below indicates year of this printing:

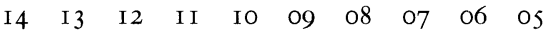

Typeset by G\&S Book Services in I0.5/12.5 Bembo 
For Ellie, Nate, and Lynn 
